\title{
THE CHEMICAL CONTROL OF CLOSED CIRCULATING SYSTEMS OF SEA WATER IN AQUARIA FOR TROPICAL MARINE FISHES
}

\author{
By C. M. Breder, JR., AND T. H. Howley \\ New York Aquarium
}

\section{INTRODUCTION}

(Figs. 332-344 incl.)

The present paper ${ }^{1}$ is intended as the first of a series concerning the control of aquatic environments based on studies carried on in the laboratory of the New York Aquarium. Considering for how long a period of years both public and private aquaria have been maintained, little has been done in attempting to maintain the water in a suitable chemical condition. In a measure, at least, this is due to ignorance of the chemistry involved on the part of those in charge. In the present case, for example, the authors have for the most part been involved with matters of ichthyology and fish culture respectively. It was necessary for them in this instance to practically abandon their ordinary pursuits and delve into the intricacies of modern chemical practice. In this we have been aided by Dr. Homer Smith and Mr. N. Farnacci of Bellevue Medical College, New York University.

The chemical data set forth herewith has been purposely written in language as non-technical as possible for the group it is intended to reach is one of naturalists. While the paper is intended primarily for those concerned with care of aquaria, it is hoped that it may also be of use to individuals holding fishes under experimental conditions in laboratories. The discussion is purposely confined to large systems of circulating water, but obviously the principles set forth also apply to small, standing aquaria of salt water. It is planned, however, to discuss the latter in a subsequent paper of this series.

1 A preliminary note is given by Breder, 1930. 


\section{PRINCIPLES INVOLVED ${ }^{1}$}

Any system for the maintenance of salt water fishes for exhibition, study or experimental purposes such as considered herein consists essentially of a series of aquaria which drain through a filter to a storage reservoir from which the water is pumped to a distributing tank which feeds the aquaria. Figure 332 illustrates the basic elements of all such systems and is a schematic representation of the one employed at the New York Aquarium. To this is added a suitable heating plant for winter use at this institution. Such systems usually contain a negligible quantity of plant life other than a little unicellular algae, whereas they do contain a vastly greater number of aquatic animals than a similar volume of water in the open sea. If it were possible to maintain a proper amount of plant life in such a system, interactions would take place that would largely obviate the methods herewith discussed.

\section{EFFects of Fishes on WATER}

With the conditions so stated we may consider what happens to the sea water in such a system. The animals, usually mostly fishes, bring about the following changes:

Respiration

1. The oxygen dissolved in the water decreases as it is consumed by the fishes.

2. The dissolved carbon dioxide $\left(\mathrm{CO}_{2}\right)$ increases as it is produced by the fishes and by hydrolysis forms carbonic acid $\left(\mathrm{H}_{2} \mathrm{CO}_{3}\right)$ which tends to make the water more acid.

\section{Excretion}

The excreta of fishes may be either solid or fluid as in other animals. The fluid wastes usually immediately go into solution and react with substances already present, while the solids for the most part dissolve slowly. Those wastes that are removed by filtration do not concern us here. The dissolved substances are of course not removed by filtration and tend to accumulate in the sea water. These waste products all primarily derived from the food fed to the fishes, include organic metabolites such as urea, ammonia,

1 See Harvey 1928 for a recent comprehensive treatise on chemical conditions in the open sea. 
uric acid, creatine, creatinine or inorganic salts such as calcium, magnesium, sulphates, phosphates, etc. Some of these substances are excreted in the urine and some by way of the gills (Smith 1929 and 1930).

The experience of others and numerous observations of our own lead us to conclude that the most important changes in sea water resulting from continued use involve the acid-base equilibria. The continued excretion of acid metabolites (principally sulphates) leads on the one hand, to a reduction of the normal bicarbonate content while the continued production of $\mathrm{CO}_{2}$ by the fish on the other hand increases the free $\mathrm{CO}_{2}$ in the water. Both of these changes tend to increase the acidity. The accumulation of free $\mathrm{CO}_{2}$ can be prevented by thorough aeration of the water but the depletion of the bicarbonates cannot be prevented and consequently this change can only be rectified by the artificial addition of bicarbonates from time to time.

The fate of the nitrogenous substances is unknown, but it appears that they are quickly oxidized to ammonia, which escapes from the water during aeration. No more than traces of ammonia or organic nitrogen have been found in our aquarium sea water after twenty years of use (Townsend 1929). There is a gradual accumulation of nitrates but it is probable that in the quantities present these innocuous salts are not deleterious.

\section{Food}

The quantities as above mentioned are primarily introduced indirectly as food whereas the protein sulphur etcetera in the food oxidize to produce sulphuric and other non-volatile acids which react with the bicarbonates forming neutral sulphates and other salts.

\section{Tank Fittings}

The rock and cement work if properly seasoned affect the system no more than the natural rocks and corals of the sea bottom. If the calcium rocks are attacked, this is in itself an indication of a too acid system. The metals employed in the piping and pumps should not influence the general run of aquarium fishes. ${ }^{1}$

1 The long discussed toxic effect of certain metals on aquatic animals usually appears to be of significance only in waters that are much less buffered than sea water. 


\section{Density}

The evaporation of water and the addition of salts introduced in the foods, increase the specific gravity and osmotic pressure above the normal.

Concluding this brief outline we may list the most important changes occurring in a closed system of sea water as:

1. Oxygen decreases.

2. Carbon dioxide increases.

3. Bicarbonates are displaced by acid metabolites. ( 2 and 3 lead to increased acidity).

4. Density increases.

\section{MEthods OF CORRECTION}

Methods of correcting these changes will now be described.

\section{Oxygen and carbon dioxide}

The invasion and evasion of oxygen from air to water is rapid and a very small amount of aeration will nearly saturate the water with oxygen. A slight degree of undersaturation is apparently without effect on the majority of fishes. But a slight accumulation of free $\mathrm{CO}_{2}$ is sufficient to make the sea water perceptibly more acid and to render it deleterious. Ocean water contains little $\mathrm{CO}_{2}$. It is our experience that the ordinary aeration system is inadequate to keep the free $\mathrm{CO}_{2}$ down to the normal level and consequently an increase in the quantity of this substance present in poorly aerated water accounts in part for its increased acidity. This accumulation of free $\mathrm{CO}_{2}$ tends to make the water more acid but this result is also brought about in part by a decrease in the bound $\mathrm{CO}_{2}$ or bicarbonate. ${ }^{1}$

As previously pointed out, the oxidation of protein sulphur etcetera in the food fed to the fishes leads to the formation of sulfuric and other non-volatile acids which on being excreted into the seawater react with the bicarbonates and displace the bound $\mathrm{CO}_{2}$ forming neutral sulphates and other salts. In view of the above chemical relationship this displacement of bicarbonates is very

1 The hydrogen ion concentrate $(\mathrm{pH})$ of a solution is determined by the ratio between the free $\mathrm{CO}_{2}$ and the bound $\mathrm{CO}_{2}$. According to the equation

$$
\log \frac{1}{\mathrm{~K}}+\log \frac{\left[\mathrm{HCO}_{3}\right]}{\left[\mathrm{CO}_{2}\right]}=\mathrm{pH}
$$

where $k$ is the dissociation constant of carbonic acid. The $\mathrm{pH}$ will decrease if either $\mathrm{HCO}_{3}$ (related to bound $\mathrm{CO}_{2}$ ) is decreased or $\mathrm{CO}_{2}$ (related to free $\mathrm{CO}_{2}$ ) is increased. 
significant because it not only leads to increased acidity of the water but it reduces the most important buffering salt of the water itself and deprives the living fish of chemical protection afforded by the buffer. From all considerations it would appear that a reduction in bicarbonate content would be just as deleterious as an increase in free $\mathrm{CO}_{2}$.

$$
\begin{aligned}
& \text { Simultanous action } \\
& 2 \mathrm{NaHCO}_{3}+\mathrm{H}_{2} \mathrm{SO}_{4} \rightarrow \mathrm{Na}_{2} \mathrm{SO}_{4}+2 \mathrm{H}_{2} \mathrm{CO}_{3} \\
& \mathrm{H}_{2} \mathrm{CO}_{3} \rightarrow \mathrm{CO}_{2}+\mathrm{H}_{2} \mathrm{O}
\end{aligned}
$$

As remarked above, the excess free $\mathrm{CO}_{2}$ can be removed by adequate aeration, ${ }^{1}$ but the depletion of bicarbonates can only be corrected by adding the salt in sufficient quantities from time to time to hold its concentration in the water at a normal level. This can be done most suitably by adding Sodium bicarbonate $\left(\mathrm{NaHCO}_{3}\right)$ since sodium is the most abundant base in sea water (about 80 per cent of the total base).

Normal sea water contains about 2.1 millimols of bicarbonate per liter. In order to keep the salt at this level we have found it necessary to add to our aquarium system, holding about 50,000 gallons or 227.000 liters of sea water, 73.19 kilograms of $\mathrm{NaHCO}_{3}$ in a period of six months. A very long period would be required before an increase in $\mathrm{Na}$ would be significant. ${ }^{2}$

After the present method of treatment had been in operation for six months Mr. N. Farnacci kindly made the following analysis (Table 1) as a further check against any inherent difficulties not apparent by the analytical methods employed at the Aquarium. A sample of water brought from Nassau, Bahamas, was analysed at the same time for comparative purposes.

How closely our water resembles that of West Indian coral reefs

1 At this writing the New York Aquarium system is not entirely adequate in this regard, but work is under way to remedy this remaining defect.

${ }^{2}$ Dec. $19 / 29$ to June $19 / 30=6$ months

73,191 g. $\mathrm{NaHCO}_{3}$

50,000 gals. water $\quad=227,000$ liters

$=.322 \mathrm{~g} / \mathrm{L}$

$.84 \mathrm{~g}$.

$=0.4$ millimol per liter added

$\frac{0.4}{2.2}=$ about $20 \%$ of original bicarbonate replaced in 6 months. With $440 \mathrm{mM}$ of $\mathrm{Na}$ present this added $\mathrm{NaHCO}_{3}$ increases the $\mathrm{Na}$ by 0.1 per cent. It would require five years to increase $\mathrm{Na}$ by 1 per cent, at the rate of 0.1 per six months. 
is evident from this table. For comparison with a large number of analyses see Olsen 1926 and Harvey 1928.

\section{Density}

The density is not only increased by evaporation but also by the addition of sodium bicarbonate, the former being by far the more important. The correction of this is simply a matter of dilution with the proper amounts of fresh water.

The changes from which such sea water suffers may be relisted here (Table 2) with the methods for their control.

While it is not claimed that other factors are of no consequence we believe that the most important are proper aeration, density and bicarbonate content.

After a considerable period of laboratory trial the entire warm salt water system was treated as above described with results that were even more satisfactory than we had hoped for. Some of the outstanding achievements are listed below, although this program has been a matter of routine for only six months, at this writing.

The only other Aquarium that we know of that attempts a systematic chemical control is that attached to Plymouth Biological Station in England. In a personal communication, Dr. W. R. G. Atkins, Deputy Director, states that they maintain the $\mathrm{pH}$ of their water between 8.0 and 8.3 by the weekly addition of lime. For their circulation of about 50,000 gallons they find about a pound a week sufficient. However, they refresh their system with new sea water about every six months. Such treatment maintains the $\mathrm{pH}$ and accomplishes buffering but disproportionately increases the calcium content.

Mr. R. Dorn on a recent visit to the Berlin Aquarium learned that they refreshed their supply at similar intervals in quantities about equal to half their needs making up the difference with water in which had been dissolved the principal salts found in sea water in their natural proportions.

With the present data available it might well be possible to synthesize a fluid sufficiently like sea water to be satisfactory, for inland aquaria. However, it is doubtful if such would be as useful as natural sea water when obtainable.

\section{Results OBTAINED}

As evidence of the validity of the present method of treatment, 
the following list is given of the partial and more evident improvements in the condition of the fishes.

\section{Appearances}

The colors of the fishes all showed a rapid and decided improvement, especially notable in the case of the more brilliantly colored reef fishes which formerly faded out rapidly to ghost-like shadows of themselves in a few months. For example, the Nassau groupers, Epinephalus striatus Bloch, instead of becoming blanched whitish fishes with a simple black peduncular saddle, now always show a variety of their striking natural color phases. The matter of color change is also very marked, fishes which normally display such changes responding on much slighter stimulus than was heretofore necessary and with greater frequency. Squirrel fish, Holocentrus adscensionis (Osbeck), retain their brilliant red color in a fashion unknown to us before. The silvery fishes such as pompanos, Trachinotus carolinus Linnæus, and glacus (Bloch), mullet, Mugil cephalus Linnæus, etcetera instead of fading to a dead whitish as formerly, show the argenteus flashing characteristic of their kind to a marked degree. The more somber colored fishes such as black drum, Pogonias cromis (Linnæus), channel bass, Sciænops ocellatus (Linnæus) striped bass, Roccus lineatus (Bloch), jewfish, Promicrops itiaria (Lichtenstein) all show a sparkle and clearness of color rare or unknown formerly after a month's confinement.

\section{Feeding}

The appetites of the various fishes became strongly marked. Many species formerly of delicate appetites requiring much coaxing to feed at all became ravenous.

The sand sharks, Carcharias littoralis (Mitchill) have to be fed with care, so rapid is their strike for food. Several times the attendant came close to having his hand caught in their ravenous maws. Various grunts (Hæmulidæ), usually light feeders, take food freely.

\section{Activity}

Fishes formerly of very quiet habits became much more active, greatly enhancing their exhibition value. Among those showing these characteristics are the squirrel fish, jewfish, morays (Lycodontis), groupers, hinds and toadfish, Opsanus tau (Linnæus). 


\section{Mortality ${ }^{1}$}

During this period of six months referred to, the mortality has been exceedingly low and many species which we were never able to keep for any length of time now thrive. Among the latter are listed bluefish Pomatomus saltatrix (Linnæus) and shellfish, Lactophrys bicaudalis (Linnæus). It must be remembered that these fishes were kept for nearly as long as they were able to stand the system prior to the establishment of the method here described. Thus they built themselves up from a much weakened condition. Of the few losses during this period, about 90 per cent of these were due directly to fighting which is discussed below.

\section{Fighting}

One of the results not anticipated was the development of excessive fighting in many cases. The fishes have always been placed according to their ability to get along with one another and this was an entirely new development. Of course this cannot be considered as desirable, but it is a splendid evidence of the health of the fishes which formerly lacked the exuberance to quarrel.

For example, losses of Squirrel Fish were entirely due to fighting, as they would literally stab each other in their large eyes with the sharp opercular spines. Formerly we considered this species entirely peaceful. Green morays, Lycodontis funebris Ranzani, fought more violently and savagely than ever before and several losses were so exacted. The savageness of the sand sharks was marked as was that of the surgeon fishes, Acanthurus biahans Castelnau. Probably the most striking was the case of the shark suckers, Echeneis naucrates Linnæus, formerly a most innocuous fish. They began attacking

1 Unfortunately the mortality and other records are impossible of direct statistical comparison as there are various factors inherent in them that vitiate the significance of the figures arrived at. In brief, they could be used to prove anything, dependent on their interpretation. For example, there is nothing to show the size of the specimens by "counting noses" or to give even an approximate idea of the bulk of fish life in relation to the volume of water in circulation or the actual condition of the water at the time. For example, 100 triggerfish might mean 100 two-inch fish or 100 fourteen-inch fish; 10 groupers might mean 10 six-inch or 10 two-foot specimens. Of this much we are certain, however. In the nine years that the writers have been employed at the New York Aquarium, each spring found us in the position of trying to "spread" the collection to make the best possible showing and looking forward to the first new shipment anxiously. This of course has been the unfortunate, but common, experience of all those charged with the care of marine aquaria employing a permanently closed system. This spring found us in the reverse position with tanks full. When a shipment of rare Pacific fishes arrived, the problem was one of what could be done to display them without overtaxing the system. That the fishes received last year were not of any unusual vitality is borne out by the fact that the losses were normal until checked by the introduction of appropriate treatment. 
sting rays, Dasyatis centrura (Mitchill) inserting their long lower jaws in the spiracular pit and raking upward and downward with their sharp teeth thus leaving ugly scars. These are not single cases but were all repeated from time to time or until a rearrangement of species could be made.

\section{Injuries}

Injuries due to fighting or other causes healed with remarkable speed. Formerly a fish sustaining any but the most trifling wounds was as good as dead. Now cow-nosed rays, Rhinoptera quadrilobata (Le Sueur) and sting rays attacked by sand sharks heal the most surprising gashes as do the surgeon fishes after quarreling. Sea bass, Centropristes striatus (Linnæus), and spiny boxfish, Chilomycterus schœpfii (Walbaum) always subject to broken tails which sloughed away, eventually killing the fish, no longer present this problem. Those which displayed such lesions when the corrective measures were applied have healed and regenerated their lost caudal appendages. Lesions on the heads of certain groupers caused by removing parasites also healed beyond all expectations.

Growth

The growth of many fishes has been startling. A bluefish, a species we could not even keep formerly, nearly doubled its length in this time. Sea bass formerly just "hanging on" show a good increase in size.

\section{Parasites}

Although parasites are present in apparently increased quantities, they are not nearly so disastrous as formerly and have not exacted any particular toll. Probably the fishes are much more resistant to their inroads. Their effective control is probably now, nevertheless, our most important problem concerning tropical marine fishes.

It is for the totality of the above reasons that we are so well satisfied with the results of this method of procedure.

\section{TECHNIQUE}

The technique by which the preceding results were obtained is described in full detail below. ${ }^{1}$ While it may be subject to various improvements it has shown itself to be exceedingly simple and

1 Shelford 1929 gives numerous useful suggestions. 
satisfactory as described. The application of the technique divides into two parts, that of analysis of the sea water and that of the application of corrective measures. It is, of course, impossible to intelligently apply the correction until we know how much is required and how often to apply it, all of which is to be determined only by proper analysis of the water. As this will vary with each system and within the system from day to day depending on the number of fishes, their activity etcetera, it is necessary to make such analysis from time to time. At the New York Aquarium, after the system was working properly and the corrective apparatus functioning, we have found once a week to be sufficient with supplementary observations when new fishes were introduced or other changes made. As analysis necessary for setting the machines should take not over an hour when the operator has acquired some skill, it is not costly of time.

\section{ANALYSIS OF SEA WATER}

Directions for making the necessary analysis are given below.

\section{Oxygen}

A determination of this quantity is not necessary for the present purposes, for in the correction of the carbon dioxide oxygenation is amply provided for. In other words if the carbon dioxide is proper the oxygen must be in such a system. The Winkler method has been used at the New York Aquarium to check this statement as well as for other purposes not significant here. It is fully set forth elsewhere (American Public Health Association 1925).

\section{Carbon dioxide}

Tropical ocean water contains almost no free carbon dioxide. The addition of a few drops of phenolpthalein to a $10 \mathrm{cc}$. sample in a test tube will yield a pale pink color. If it fails to do this it means that aeration has been insufficient to reduce it to a normal quantity and indicates the establishment of a more efficient aeration system. In taking this sample care must be exercised to avoid aerating the sample and obtaining a false reading. When working on such an aeration system it is desirable to obtain a quantitive measure of how much free carbon dioxide is present for the presence of more than four or five p. p.m. is undesirable and should be corrected. This may be done as follows: 
Collect sample by syphoning into a glass stoppered bottle of about $500 \mathrm{cc}$. in such a manner that there are several changes of water obtained. Figure 333 illustrates a sample collector adequate for such purposes. This should be done with as little disturbance as possible as agitation of the water reduces the amount of dissolved $\mathrm{CO}_{2}$. Use immediately. Carefully pour into a 100 cc. Nessler tube up to the engraved mark. Add 10 drops of 0.5 per cent phenolphthalein solution and insert a glass stirring rod. Stir without withdrawing the rod, but raising and lowering it rapidly to insure a vertical distribution. Titrate with sodium hydroxide $\mathrm{N} / 44$ from a 25 cc. burette until a faint but permanent pink color is produced. ${ }^{1}$ Figure 335 illustrates the apparatus necessary.

The free carbon dioxide in parts per million is equal to 10 times the number of cc. of $\mathrm{N} / 44$ sodium hydroxide used.

\section{Alkalinity}

A measure of alkalinity is necessary, chiefly as a check against the preceding and following readings. ${ }^{2}$ Each read in a different manner, and although calculation is possible it is best to make all three as the possibility of error is reduced to the vanishing point because of their interrelation. While it is not necessary to go into the explanation the scale of measurement of this quantity as here employed, it may be said that it is an indirect expression of the number of free hydrogen ions present and is known as the $\mathrm{pH}$ scale. Such water as we are dealing with should not vary beyond 8.0 to 8.4. Preferably it should be about 8.2 to 8.3. Colorimetric methods are entirely sufficient for the present purposes and devices may be bought in sets for such use with complete instructions. They are as simple to operate and read as an hydrometer and require no technical skill. ${ }^{3}$ Figure 334 shows an elaborate equipment covering the entire range of natural waters, both fresh and salt.

\section{Bicarbonates}

This is by far the most important measure and also the least

1 For purposes of comparison a few drops may be added to plain sea water and shaken until pink.

${ }^{2}$ Reiss and Vellinger $1929 \mathrm{a}$ and $\mathrm{b}$ show changes in such readings at another institution in comparison with the open sea.

${ }^{3}$ Any chemical supply house will offer a number of makes. At the New York Aquarium we have used both the La Motte and Helige-Klett comparators covering the range included above. 
simple to make. Two methods are described, the second far superior to the first.

Titration method: $100 \mathrm{cc}$. of sample is placed in an Erlenmeyer flask to which is added five drops of brom-cresol purple.

This is titrated with N/100 hydrochloric acid until the purple color disappears. It is then boiled, which will cause a reappearance of the color. Titration is continued alternating with boiling until the purple color fails to reappear. Figure 336 illustrates the necessary apparatus.

The burette reading in cc. multiplied by 0.0001 gives the results in per cent of concentration. As normal sea water requires from 23 to $26 \mathrm{cc}$. of acid to reach its end point, it consequently varies from 0.0023 to 0.0026 normal or 2.3 to 2.6 millimols per liter of bound $\mathrm{CO}_{2}$ or bicarbonate. ${ }^{1}$

Gasometric method: For more accurate work a Van Slyke manometric apparatus may be used. Such a device is illustrated (Fig. 337). It takes some little skill to operate, but where great accuracy is essential or where small amounts of fluid are only available (as in small balanced aquaria) it is particularly valuable. Details of operation for the estimation of $\mathrm{CO}_{2}$ as used at the New York Aquarium, follow: ${ }^{2}$

With the apparatus in readiness $1.3 \mathrm{cc}$. of distilled water is introduced in the graduated cup "A." Exactly 2 cc. of sample is admitted to it from a Van Slyke pipette by means of its glass stop cock. The tip of the pipette is placed below the surface of the distilled water. This prepared sample is introduced into the evacuating chamber by means of cock "B." Four drops of 10 per cent lactic acid are dropped in cup " $A$ " and admitted to the chamber the same way and washed in with mercury the last of which is left as a mercury seal in the "neck" of the cup. Reservoir " $C$ " is then lowered until the mercury meniscus in the evacuating chamber stands at the mark near its base. The cock " $\mathrm{D}$ " is closed and " $\mathrm{C}$ " returned to its rack. The mixture is then shaken by means of the motor for two minutes. The chamber is brought to a vertical position if necessary and cock " $\mathrm{D}$ " opened slowly until the meniscus of the sample

1 There is an inherent error in this method causing the reading to be a little high. Thus 2.3 to $2.6 \mathrm{mM}$ corresponds to about 2.0 to 2.3 by the more accurate Van Slyke method. Accordingly, proper allowances should be made.

2 General instructions come with the instrument. See also Van Slyke 1927a, Van Slyke \& Neill 1924, Barrington \& Van Slyke 1924, Hawk \& Bergeim 1927 and Shelford 1929. 
reaches the uppermost mark. A reading is then taken on the manometer tube and cock " $\mathrm{D}$ " opened. Three drops of $5 \mathrm{~N}$ sodium hydroxide are added to the cup "A," drawn into the chamber and washed in with mercury again allowing some to remain in the cup as a seal. Reservoir " $\mathrm{C}$ " is lowered until the level of the mercury reaches about the middle of the chamber and cock "D" closed and " $\mathrm{C}$ " returned to its rack. The meniscus of the sample is again brought to the uppermost mark and a second reading taken and the temperature noted.

The following calculation gives the total $\mathrm{CO}_{2}$ in millimols $(\mathrm{mM})$.

Reading 2 is subtracted from reading 1 . This figure is multiplied by the appropriate temperature factor which is given in the accompanying table (Table 3). The result is divided by 2 . From this is deducted a similar result previously determined for the distilled water used. ${ }^{1}$

As the sea water we are concerned with should contain practically no free $\mathrm{CO}_{2}$ by first aerating the sample in a shaker (Fig. 337) until it turns phenolphthalein pink direct comparisons may be made with ocean water. ${ }^{2}$

After taking any measurement the chamber should at once be emptied. About 2 cc. of lactic acid should then be introduced, evacuated, shaken and washed into the waste bottle by means of cock "B."

\section{Density}

Density is measured by an ordinary hydrometer most conveniently marked in degrees specific gravity. This is usually made to read correctly at $15^{\circ} \mathrm{C}$. or $60^{\circ} \mathrm{F}$. The water may be brought to that temperature or the chart shown in Fig. 338 may be used. The latter is quite accurate enough for all practical aquarium purposes. ${ }^{3}$ The recommended form of hydrometer and cup is shown in Fig. 339. We consider such a glass cylinder preferable to a metal cup with a

1 This figure is determined in the same manner using 2 cc. of distilled water instead of a sea water sample and in calculating dividing by 3.5 instead of 2 because the total quantity of fluid is concerned.

2 Although open to criticism on theoretical grounds this reading deducted from a similar one on an unaerated sample serves to separate bound from free $\mathrm{CO}_{2}$. However, it is amply accurate for the present purposes and much easier and more satisfactory in the hands of anyone not experienced in chemical methods than is the titration method. A small chemical aspirator will be found equally suitable for this purpose.

${ }^{3}$ Based on figures in Schureman 1929. 
built in thermometer because greater accuracy in reading is possible. ${ }^{1}$

Sea water suitable for tropical marine fishes shows characteristics similar to those given in (Table 4), based on samples collected at various places. Those of Bahama waters were made possible by the generosity of Mr. Daniel Bacon and those of the Pacific by Mr. Vincent Astor. The latter were collected by W. S. Bronson especially for this purpose while the former were one of the objectives of an expedition by the senior author. Dr. J. N. Gowanloch kindly collected the Florida samples while at the Carnegie Station at Dry Tortugas.

\section{Application of CoRrective Measures}

The technique of applying the suitable corrective measures are given below. They are three in number and interrelated to the extent that are the factors they control.

\section{Carbon dioxide}

By far the most suitable method for controlling the free $\mathrm{CO}_{2}$ concentration is by any means of agitation which will insure its evasion to the point at which a few drops of phenolphthalein will turn pink. That amount, however, is much more than usually provided in aquaria. Open troughs with baffles, drops through open air, sprays into air, and air pumped through tanks, any or all may be employed to obtain the desired effect. Sea water left standing, after filtering, in a reservoir either in light or darkness, will correct itself in a time dependent on the size, shape and ventilation of the reservoir and the condition of the water when introduced. This method is not important, however, as the water returns with surprising rapidity to the normal high level of a system, taking usually less than two days. If it were not for this fact, a divided reservoir allowing part of the supply to be recuperating at all times, would be useful.

Of methods applicable to aquaria probably the most rapidly effective is that of a stream of water thrown into the air acting as a fountain. Following this in efficiency, we would place an open trough with suitable baffle or riffle boards and free drops from a

1 See Service 1928. Titration with silver nitrate, a more accurate method for open sea water, loses its value here owing to the possibility of a larger variation in the proportions of the dissolved salts. As it is the osmotic pressure that concerns us chiefly in this regard, where greater accuracy is required, freezing point determinations should be used. 
higher level. One of the most misunderstood methods is that of introducing a fine spray of air bubbles into the water. This method gives a considerable visual effect but is measurably less efficient than generally supposed. Buswell (1928) has shown that bubbles rising freely through the water carry a film with them that greatly decreases the apparent efficiency. No attempt will be made here to outline structural methods of devices for aeration, as the proper design depends on the particular needs of each institution. The amount required depends on the following factors:

1. Amount and kinds of fishes in relation to the amount of water in circulation.

2. Surface of water exposed to air in relation to volume.

3. Specific gravity in relation to $\mathrm{pH}$ value and bicarbonates in solution, used in the system.

In the above discussion, it is supposed that where the water is in contact with air the latter is normally pure. Conditions in closely confined places do not allow a rapid evasion of $\mathrm{CO}_{2}$ and should be appropriately ventilated. ${ }^{1}$

The possibility of supersaturation, principally with nitrogen and its attendant difficulties, may be guarded against by having the aerating device relatively remote in the system from the fishes, thus allowing the water to reach equilibrium before entering the aquarium tanks.

Another method might be employed but due to the danger it brings it is considered unwise. If in treating for the bicarbonate balance sodium hydroxide be used instead of sodium bicarbonate, the subsequent reactions make use of the free $\mathrm{CO}_{2}$ in the water $\left(\mathrm{NaOH}+\mathrm{CO}_{2}=\mathrm{NaHCO}_{3}\right)$. In the sodium bicarbonate $\left(\mathrm{NaHCO}_{3}\right)$ the union has already been made and the free $\mathrm{CO}_{2}$ of the water is untouched. Thus the use of sodium hydroxide would be a very satisfactory means of effecting two desired results by one method, but for the following reasons. The drawback is associated with the possibility of adding a little excess of the correcting substance. In the case of the sodium bicarbonate nothing worse happens than that the bicarbonate quantity rises in proportion to its amount, pro-

\footnotetext{
${ }^{1}$ In localities high above sea level due to the lower barometric pressures at a given temperature, less gases will remain in solution. Under such conditions, the evasion of $\mathrm{CO}_{2}$ should be more rapid, although offsetting this, the dissolved oxygen would be correspondingly small. We do not know if there would be a practical upper limit due to this in mountain regions.
} 
portionately increasing the $\mathrm{pH}$ and the specific gravity. In the case of the sodium hydroxide as soon as all the $\mathrm{CO}_{2}$ has combined the further addition of $\mathrm{NaOH}$ remains in solution in that form causing a very rapid and dangerous increase in $\mathrm{pH}$ easily passing out of the range it is possible for fishes to exist. in. This danger is also inherent in the use of $\mathrm{Ca}$ which is employed in the Plymouth Aquarium, as previously mentioned.

$$
\begin{gathered}
\mathrm{NaOH}+\mathrm{H}_{2} \mathrm{CO}_{3} \rightarrow \mathrm{NaHCO}_{3}+\mathrm{H}_{2} \mathrm{O} \\
\mathrm{Ca}(\mathrm{OH})_{2}+\mathrm{H}_{2} \mathrm{CO}_{3} \rightarrow \mathrm{CaCO}_{3}+2 \mathrm{H}_{2} \mathrm{O}
\end{gathered}
$$

While it is recognized that further study may show a way to automatically check such a catastrophe, it is considered safest at the present time to aerate for the removal of free $\mathrm{CO}_{2}$ and correct the bicarbonate balance by adding $\mathrm{NaHCO}_{3}$.

\section{Bicarbonates}

When the bicarbonates read too low as determined by the analysis previously outlined they may be brought back to their proper range by the simple addition of sodium bicarbonate to some point in the system, such as a duct leading to the reservoir, where it will become thoroughly mixed before coming in contact with the fishes themselves. This of course will cause a rather sudden return to the desired condition and it is much better practice to add it steadily in small quantities in such a manner that it holds the bicarbonate at a constant and normal level, this avoiding the shock of spasmodically varying the chemical quantities. For this purpose the device shown (Figs. 340, 341, 342) was found to be highly satisfactory. ${ }^{1}$

The vital part of the machine consists of a glass tube bent as shown (Figure 341). This is run through a square brass tube rocking on an axel. The cup at the far end when filled with water automatically tips it up. When the cup empties, the tube returns to its original position. The frequency of this tipping action is regulated by a valve controlling the amount of water employed as does the adjustable counterweight on the other end of the brass

1 This device was primarily designed for use in conditioning fresh water in an open system or applying medications to fishes unable to be moved or to endure standing water. In its description it will be noted that in such use it will maintain a constant concentration of any solution employed irrespective of variations in flow. Although this feature is of little consequence in its present use, in the event of a shut down in the water supply it automatically stops, a feature of some importance. The machine's other uses will be discussed in another paper. 
tube. The glass tube dips into a glass pan of solution and draws in a few drops holding it there by capillary attraction. When the tube lifts, this amount runs down and discharges. The glass pan is kept full by an inverted bottle very much after the fashion of the common poultry drinking fountain. No dimensions are given as the proportions may be varied to suit individual needs. Since writing the above, an improvement has been made in which the supply bottle is carried in a swinging cradle. By this means the bottle may be swung neck up for filling, thereby avoiding the handling of the full bottle with its consequent possible breakage or spilling of solution.

After setting the apparatus in place, the flow is increased or decreased by regulating the cock controlling the water supply. At the New York Aquarium it was found that a bottle full of saturated solution of sodium bicarbonate would last two or three days and in a short time the flow could be so regulated as to need no other attention than to renew the supply for long periods. ${ }^{1}$

\section{Density}

When the specific gravities read too high as determined by a hydrometer, good fresh water may be added as a dilutant but here again it is much more suitable to add automatically and so keep the density at a constant level comparable to that of the habitat of the fishes concerned.

The device shown (Figs. 343, 344) is rather complicated in appearance but is based on very simple principles. A hydrometer is so arranged that it floats in a bath of the water to be controlled. When the water becomes a little too dense, the hydrometer rises and closes an electric circuit which opens a solenoid valve turning fresh water into the system. With the consequent lowering of the density, the hydrometer drops and opens the circuit. As hydrometers operate truly only at a definite temperature, it is necessary to bring that of its water supply to a constant figure. This part of the apparatus accounts largely for its complicated appearance. A water bath of constant temperature, through which the supply flows, controls this.

1 It might be thought that a common drip would be just as satisfactory. In actual practice, such was not found to be the case as it proved extremely difficult to adjust to satisfaction. 
The dimensions are immaterial but the important details of construction $^{1}$ and the wiring diagram are given (Fig. 343).

The apparatus is so made that it will not operate in the case of a failure of any part thus obviating the danger of flooding the system with fresh water. An additional precaution could be installed to ring an alarm bell in the case of the hydrometer dropping below its normal lower level.

\section{If the Control Line Fails}

The fresh-water relay will not operate.

The temperature of the water bath will rise and lower the position of the hydrometer.

\section{If the Power Line Fails}

The fresh-water valve will remain closed.

The temperature of the water bath will lower, raising the hydrometer but it will be inoperative.

Adjustment and Operation

The adjusting knob (Fig. 343) is so set that the mercury cup on the hydrometer floats just below the contact prongs at the desired density. Any increase closes the circuit allowing fresh water to reduce the density. Fresh water also enters the supply regulating chamber. This lowers the density in the salinostat chamber more rapidly than that of the main supply and the electric valve consequently closes in a period dependent on the amount of fresh water so diverted. By making use of this detail, fresh water is added in small intermittent quantities insuring a smoother and more gentle reduction of density than by allowing it to enter in a single continued flow. Thus the electric valve closes and opens continually while the water is being added until the entire system is properly reduced.

\section{Routine Procedure}

The routine procedure now employed at the New York Aquarium is described below.

\section{Analysis}

The apparatus absolutely necessary for making the essential analysis may be listed together with the required reagents.

1 The following parts of this appliance were obtained entire from various sources: Hydrometer, C. J. Tagliabue Co.; Thermoregulator, relays and resistance, American Instrument Co.; special glass ware, Eimer and Amend Co. 
1. 3 dropping bottles with pipettes (about $30 \mathrm{cc}$.)

2. 1 test tube (about 50 cc.)

3. 1 Comparator of ample ran e

4. 1 Van Slyke constant volume manometric apparatus

5. 1 Van Slyke pipette with stop cock (2 cc.)

6. 1 hydrometer marked in degrees Sp. G. 1.000 to 1.030

7. 1 engraved glass thermometer about $0^{\circ}$ to $50^{\circ} \mathrm{C}$. (or its equivalent in Fahrenheit)

8. 1 glass hydrometer jar.

If it is desired to titrate for bicarbonates instead of measuring them gasometrically, omit items 4 and 5 and 1 dropping bottle and substitute the following:

1. 150 cc. burette

2. 1200 cc. Erlenmeyer flask

3. 1 Electric hot plate (or other heat source)

4. 1100 cc. graduate.

If it is desired to titrate for the amounts of free $\mathrm{CO}_{2}$ present add the following:

1. 125 cc. burette

2. 1100 cc. Nessler tube

3. 1500 cc. bottle with glass stopper.

4. 1 glass stirring rod.

The reagents necessary follow:

Phenolphthalein solution $0.5 \%$

Lactic acid solution $10 \%$

Sodium hydroxide $5 \mathrm{~N}$.

For titrating for bicarbonates add:

Brom-cresol purple 4\%

Hydrochloric acid N/100 (exactly).

For titrating for free $\mathrm{CO}_{2}$ add:

Sodium hydroxide N/44 (exactly).

With this equipment, the procedure should be as follows:

Take $\mathrm{pH}$ of sample on comparator.

Test presence of free $\mathrm{CO}_{2}$ with phenolphthalein.

Measure total $\mathrm{CO}_{2}$ on Van Slyke apparatus. 
Measure bicarbonate $\mathrm{CO}_{2}$ of aerated sample on Van Slyke apparatus.

Take specific gravity and temperature.

These items should be recorded as taken, on some such form as suggested below which becomes part of the permanent records of the institution.

\begin{tabular}{c|c|c|c|c|c|c}
\hline Date & $\mathrm{pH}$ & $\begin{array}{c}\mathrm{mM} \text { total } \\
\mathrm{CO}_{2}\end{array}$ & $\begin{array}{c}\mathrm{mM} \text { bound } \\
\mathrm{CO}_{2}\end{array}$ & $\begin{array}{c}\mathrm{mM}^{\mathrm{M}} \\
\mathrm{CO}_{2}\end{array}$ & $\begin{array}{c}\text { Sp. G. } \\
\text { at } \\
15^{\circ} \mathrm{C} .\end{array}$ & $\begin{array}{c}\text { Tempera- } \\
\text { ture. }\end{array}$ \\
\hline May 15, 1930 & 8.2 & 2.254 & 2.201 & 0.053 & 1.0261 & 72 \\
\hline
\end{tabular}

The $\mathrm{pH}$ is read directly from the comparator. The total $\mathrm{CO}_{2}$ is calculated from the Van Slyke readings. The bicarbonate reading is practically identical and need not be taken if the sample turned pink on the addition of phenolphthalein. If it did not, a sample aerated until it shows this reaction will read less. The free $\mathrm{CO}_{2}$ is obtained by deduction of the bicarbonate $\mathrm{CO}_{2}$, in such a case, from the total $\mathrm{CO}_{2}$. The specific gravity and temperature are taken together. The former is corrected to $15^{\circ} \mathrm{C}$. by means of Fig. 338 .

If free $\mathrm{CO}_{2}$ is present in a measurable quantity, it will modify the figures as follows:

The bicarbonate $\mathrm{CO}_{2}$ will be considerably less than the total $\mathrm{CO}_{2}$ and the free $\mathrm{CO}_{2}$ will be relatively high. (This will follow only when phenolphthalein does not turn the unaerated sample pink.) The $\mathrm{pH}$ will be lower for the untreated sample than for the aerated sample. ${ }^{1}$

If the bicarbonates are too low the bicarbonate $\mathrm{CO}_{2}$, will read less than $2.100 \mathrm{mM}$ and the $\mathrm{pH}$ will be low. The presence of relatively large amounts of free $\mathrm{CO}_{2}$ goes along with too little bicarbonate. (Free $\mathrm{CO}_{2}$ is normally present in larger quantities in waters of low salinity.) The specific gravity should not be above 1.0265 . If the salinostat is operating, this will automatically be maintained. A recording thermometer is a valuable adjunct as it shows at once any vagaries in temperature and affords a complete check of this factor.

1 The relations are not as here described if the water is seriously out of its normal range. Such a condition shows a badly upset system. 


\section{Corrective measures}

With this knowledge at hand, the control applicances may be adjusted to the needs. The complete apparatus is listed below:

1. Sufficient aeration apparatus to reduce the free $\mathrm{CO}_{2}$ nearly to zero.

2. A bicarbonate corrector as herein described.

3. A salinostat as herein described.

The only reagent necessary is an ample supply of sodium bicarbonate.

If the bicarbonate $\mathrm{CO}_{2}$ of the aerated sample reads too low the valve above the tipple bar of the bicarbonate corrector is opened a little more; if it reads too high, it is closed a little. Finer adjustment is obtained after approximately the correct figure is secured by regulating the second valve which "bleeds" the line running to the tipple cup.

If the specific gravity is either too high or too low, the adjustment screw is turned down or up accordingly. When once adjusted, this should remain constant indefinitely.

With these three control measures correct, the $\mathrm{pH}$ should be within proper range. A decided variation in this or any of the others not bearing the correlation outlined, indicates that something is radically wrong either with the readings or that the sea water is being modified by some source of contamination or other cause. If it is the latter, the actions and appearances of the fishes themselves, especially the more sensitive ones will also show modification.

It is hardly necessary to remark that although both the analytical and corrective equipment require little attention, a periodic cleaning is necessary as well as an occasional check on the functioning of the moving parts in the apparatus.

In such systems of water there is always some loss due to leakage. If it were not for this, the bulk of water in circulation would actually increase as the addition of fresh water is in excess of the loss by evaporation because of the increase in density due to the addition of sodium bicarbonate and the soluble substances introduced directly or indirectly by foods. 


\section{SUMMARY}

1. The major chemical quantities in a closed system of sea water containing fishes may be readily controlled by direct chemical treatment.

2. Such treatment provides the fishes with a very close simulation of natural sea water and they consequently show a marked improvement in health and general well being over that displayed in an untreated system.

3. The accumulation of carbon dioxide may be reduced by adequate aeration.

4. The normal bicarbonates which are destroyed by reactions with the fishes' waste products may be replaced by sodium bicarbonate suitably administered.

5. The increasing density may be reduced most satisfactorily by the automatic addition of fresh water.

6. The items not provided for increase in quantities not exceeding traces. At the rate of application necessary at the New York Aquarium, the sodium concentration should not increase more than about 1 per cent in five years.

7. Full instructions are given for the use of the analytical and corrective apparatus described, two of the latter appliances being new. 


\section{BIBLIOGRAPHY}

American Public Health Association (Pub.)

1925. Standard Methods for the Examination of Water and Sewage. 1119. (Sixth Edition.) New York.

BREDER, C. M., JR.

1930. Report of the Director of the Aquarium reprinted from thirtyfourth annual report of the New York Zoological Society 1-21. 1 fig。

Buswell, A. M., Shive, R. A., ANd Neone, S. L.

1928. Bioprecipitation Studies, 1921-1927. Illinois State Water Survey bulletin 25: 1-93.

Harrington, G. R. ANd VAN Slyke, D. D.

1924. The Determination of Gases in Blood and other solutions by vacuum extraction and manometric measurement. II. J. of Biol. Chem. lxi: 575-584.

HARVEY, H. W.

1928. Biological Chemistry and Physics of sea water. MacMillan Co., N. Y.

HAWK, P. B. AND Bergeim, O.

1927. Practical Physiological Chemistry 9th edition. P. Blakiston \& Co.

Olsen, J. C. Editor

1926. Van Nostrand's Chemical Annual 6th issue 1-882. Van Nostrand Co., N. Y.

Reiss P., AND Vellinger E.

1929a. Sur le $\mathrm{pH}$ de l'eau de mer circulant dans les bassins et aquarium de la Station Oceanographique de Salammbô.

Notes-Station Oceanographic de Salammbô No. 10: 1: 7 .

1929b. Mesures du $\mathrm{pH}$ de l'eau de mer aux environs de Tunis en vue d'une application à l'etude des migrations du thon. Bulletin Station Oceanographic de Salammbô No. 15: 1: 19.

SERvice, J. H.

1928. Measurement of Salinity of Sea Water-U. S. Coast \& Geodetic Survey Special Pub. No. 147: 1-20

SHELFORD, V. E.

1929. Laboratory \& Field Ecology-Williams \& Wilkins Co., Baltimore, Md.

SCHUREMAN, $\mathrm{P}$.

1929. Instructions Primary Tide Stations. Special Pub. No. 154. U. S. Coast \& Geodetic Survey 1-53.

SmiTh, H. W.

1929. The excretion of ammonia and urea by the gills of fish. J. of Biol. Chem. lxxi: 727-742.

1930. The absorption and excretion of water and salts by marine teleosts. Amer. J. of Physiology 93. 2. 480-505. 
Townsend, C. H.

1929. The Public Aquarium, its construction, equipment and management. Appendix VII. Report U. S. Commissioner of Fisheries.

VAN Slyke, D. D.

1927a. Note on a Portable Form of the Manometric Gas Apparatus and on Certain Points in the Technique of Its Use. J. of Biol. Chem. lxxiii: 121-126.

1927b. $\mathrm{CO}_{2}$ Factors. J. of Biol. Chem. lxxiii: 127.

Van Slyke, D. D. and Neill, J. M.

1924. The Determination of Gases in Blood and Other Solutions by Vacuum Extraction and Manometric Measurement. I. J. of Biol. Chem. lxi: 523-573. 
TABLE I. ANALYSIS OF TREATED AQUARIUM WATER

\begin{tabular}{|c|c|c|c|c|c|c|c|c|c|c|c|}
\hline \multirow[b]{2}{*}{ Water } & \multirow[b]{2}{*}{$\Delta$} & \multicolumn{10}{|c|}{$\mathrm{mM}$ per liter } \\
\hline & & $\mathrm{Cl}^{\frac{1}{1}}$ & $\mathrm{SO}_{4}$ & $\begin{array}{l}\Sigma \\
\mathrm{A}\end{array}$ & $\begin{array}{l}\mathrm{CO}^{2} \\
\mathrm{H}_{2} \mathrm{CO}_{3}\end{array}$ & K & $\mathrm{Na}^{-3 / 1}$ & $\mathrm{Ca}$ & $\mathrm{Mg}$ & ${ }_{\mathrm{B}}^{\Sigma}+$ & $\begin{array}{l}\text { Fixed } \\
\text { Residue }\end{array}$ \\
\hline Circulation. & 2.029 & 553 & 30.0 & 613 & 2.1 & 10.84 & 499 & 14.97 & 42.3 & 622 & - \\
\hline \multirow[t]{2}{*}{ Nassau...... } & 2.111 & 596 & 31.4 & 659 & 2.1 & 11.39 & 537 & 12.95 & 45.0 & 664 & - \\
\hline & atm. & \multicolumn{10}{|c|}{ parts per thousand } \\
\hline Circulation. & 24.55 & 19.65 & 2.88 & 22.53 & .088 & .423 & 11.48 & .579 & 10.03 & 13.51 & 36.04 \\
\hline Nassau. . & 25.58 & 21.18 & 3.02 & 24.2 & .088 & .444 & 12.34 & .519 & 10.95 & 14.40 & 38.6 \\
\hline
\end{tabular}

${ }_{1}^{1} \mathrm{Cl}-0.35$ for $\mathrm{Br}_{2}$ and $\mathrm{I}_{2}$ gives slightly lower values.

${ }^{2}$ Includes traces of ${ }^{\prime} \mathrm{NO}_{2},{ }^{\prime} \mathrm{NO}_{3}$, and $0.2 \mathrm{mM}$ of $\mathrm{PO}_{4}$.

${ }^{3} \mathrm{Na}$ obtained by difference.

TABLE II. CHANGES AND RECTIFICATION OF AQUARIUM SEA WATER

\begin{tabular}{l|l}
\hline \multicolumn{1}{c|}{ Changes } & \multicolumn{1}{c}{ Methods of Control } \\
\cline { 2 - 2 } $\begin{array}{l}\text { 1. Oxygen decreases. } \\
\text { 2. Free Carbon dioxide increases. } \\
\text { 3. Bicarbonates destroyed. } \\
(2 \text { and } 3 \text { lead to increased } \\
\text { acidity }) .\end{array}$ & $\begin{array}{l}\text { Follows on treatment } 2 . \\
\text { Aeration. } \\
\text { Sodium bicarbonate added. } \\
\text { acidity is decreased by treat- } \\
\text { ment } 2 \text { and } 3) . \\
\text { Dilution with fresh water. }\end{array}$ \\
\hline
\end{tabular}


TABLE III. VAN SLYKE FACTORS ${ }^{1}$

\begin{tabular}{c|c||c|c}
\hline $\begin{array}{c}\text { Thermometer } \\
\text { Reading }\end{array}$ & Factor & $\begin{array}{c}\text { Thermometer } \\
\text { Reading }\end{array}$ & Factor \\
\hline 15 & .0313 & 23 & .0300 \\
16 & .0311 & 24 & .0299 \\
17 & .0310 & 25 & .0297 \\
18 & .0308 & 26 & .0296 \\
19 & .0306 & 27 & .0294 \\
20 & .0305 & 28 & .0293 \\
21 & .0303 & 29 & .0291 \\
22 & .0302 & 30 & - \\
\hline
\end{tabular}

Table to be used with a total volume of $3.5 \mathrm{cc}$. (Sample $2 \mathrm{cc}$. + distilled water $1.3 \mathrm{cc}$. + lactic acid 4 drops and sodium hydroxide 3 drops).

${ }^{1}$ From Van Slyke 1927b

TABLE IV. SEA WATER ANALYSIS

\begin{tabular}{|c|c|c|c|c|c|}
\hline Locality & Date & $\begin{array}{c}\text { Free } \mathrm{CO}_{2}{ }^{*} \\
\text { p. p. m. }\end{array}$ & $\begin{array}{l}\mathrm{CO}_{2} \text { as bicar- } \\
\text { bonates } \mathrm{mM}\end{array}$ & $\mathrm{pH}$ & Sp. G. \\
\hline $\begin{array}{c}1 \text { mile E. of Nassau } \\
\text { harbor, Bahamas... }\end{array}$ & Feb. 10,1930 & 0.0 & 2.0807 & 8.3 & 1.0265 \\
\hline $\begin{array}{c}1 \text { mile E. of Nassau } \\
\text { harbor, Bahamas, } 8^{\prime} \\
\text { bottom ........... }\end{array}$ & Feb. 10, 1930 & 0.0 & 2.1542 & 8.3 & 1.0262 \\
\hline $\begin{array}{c}\text { Nassau harbor, Baha- } \\
\text { mas . . . . . . . . . . . }\end{array}$ & Feb. 12,1930 & 0.0 & 2.2643 & 8.3 & \\
\hline $\begin{array}{l}\text { North Cay, Bahamas.. } \\
\text { North Cay, Bahamas }\end{array}$ & Feb. 12, 1930 & 0.0 & 2.0962 & 8.3 & 1.0261 \\
\hline $10^{\prime}$ bottom. . . . . . . & Feb. 12,1930 & 0.0 & 2.0617 & 8.3 & 1.0261 \\
\hline $\begin{array}{c}\text { Berry Islands, Baha- } \\
\text { mas, Frazer's Hog } \\
\text { Cay. . . . . . . . . }\end{array}$ & Feb. 14, 1930 & 0.0 & 2.0872 & 8.4 & 1.0258 \\
\hline $\begin{array}{c}\text { Nassau harbor, Baha- } \\
\operatorname{mas} . . . . . . . . . .\end{array}$ & Feb. 19,1930 & 0.0 & 2.2117 & 8.3 & \\
\hline
\end{tabular}

* By phenolphthalein sodium hydroxide titration. A more accurate measurement would show this figure to be about 0.04 p. p. m. 
TABLE IV. SEA WATER ANALYSIS (Cont.)

\begin{tabular}{|c|c|c|c|c|c|}
\hline Locality & Date & $\begin{array}{c}\text { Free } \mathrm{CO}_{2}^{*} \\
\text { p. p. m. }\end{array}$ & $\begin{array}{l}\mathrm{CO}_{2} \text { as bicar- } \\
\text { bonates } \mathrm{mM}\end{array}$ & $\mathrm{pH}$ & Sp. G. \\
\hline $\begin{array}{c}1 \text { mile E. of Nassau } \\
\text { harbor, Bahamas... }\end{array}$ & Feb. 20, 1930 & 0.0 & 2.1097 & - & 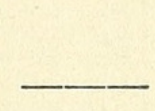 \\
\hline $\begin{array}{c}1 \text { mile E. of Nassau } \\
\text { harbor, Bahamas, } 8^{\prime} \\
\text { bottom ........... }\end{array}$ & Feb. 20, 1930 & 0.0 & 2.1572 & - & - \\
\hline Perlas Island, Panama. & - & 0.0 & 2.0948 & 8.3 & 1.0265 \\
\hline Black beach, Galapagos & $-\div$ & 0.0 & 2.1830 & 8.2 & 1.0265 \\
\hline $\begin{array}{r}0^{\prime} 27 \text { S. } 90^{\prime} 20 \mathrm{~W} \text {, Gala- } \\
\text { pagos . . . . . . }\end{array}$ & May 1,1930 & 0.0 & 2.1681 & 8.1 & 1.0261 \\
\hline $\begin{array}{r}\text { Academy Bay, Gala- } \\
\text { pagos } \ldots \ldots \ldots \ldots\end{array}$ & Apr. 3, 1930 & 0.0 & 2.1232 & 8.1 & 1.0263 \\
\hline Darwin Bay, Galapagos & & 0.0 & 2.1217 & 8.3 & 1.0265 \\
\hline Tagus Cove, Galapagos & & 0.0 & 2.1471 & 8.1 & 1.0261 \\
\hline $\begin{array}{l}\text { Loggerhead Key, Tor- } \\
\text { tugas, Fla.......... }\end{array}$ & June 8, 1930 & 0.0 & 2.0599 & 8.2 & 1.0270 \\
\hline $\begin{array}{r}\text { Garden Key, Tortugas, } \\
\text { Fla. . . . . . . . . . } \\
\text { White Shoal Tortugas. }\end{array}$ & June 8, 1930 & 0.0 & 2.1570 & 8.2 & 1.0272 \\
\hline $\begin{array}{r}\text { White Shoal, Tortugas, } \\
\text { Fla. . . . . . . . . . }\end{array}$ & June & & 80 & 8.2 & 1.0270 \\
\hline Bird Key, Tortugas.... & June 8, 1930 & 0.0 & 2.0314 & 8.3 & 1.0269 \\
\hline Rebecca Light, Florida. & June 9,1930 & 0.0 & 2.0547 & 8.2 & 1.0272 \\
\hline \multirow[t]{4}{*}{ Marquesas, Florida.... } & June 9, 1930 & 0.0 & 2.0449 & 8.3 & 1.0270 \\
\hline & Maximum & 0.0 & 2.2643 & 8.4 & 1.0272 \\
\hline & Minimum & 0.0 & 2.0314 & 8.1 & 1.0258 \\
\hline & Average & 0.0 & 2.1165 & 8.2 & 1.0265 \\
\hline
\end{tabular}




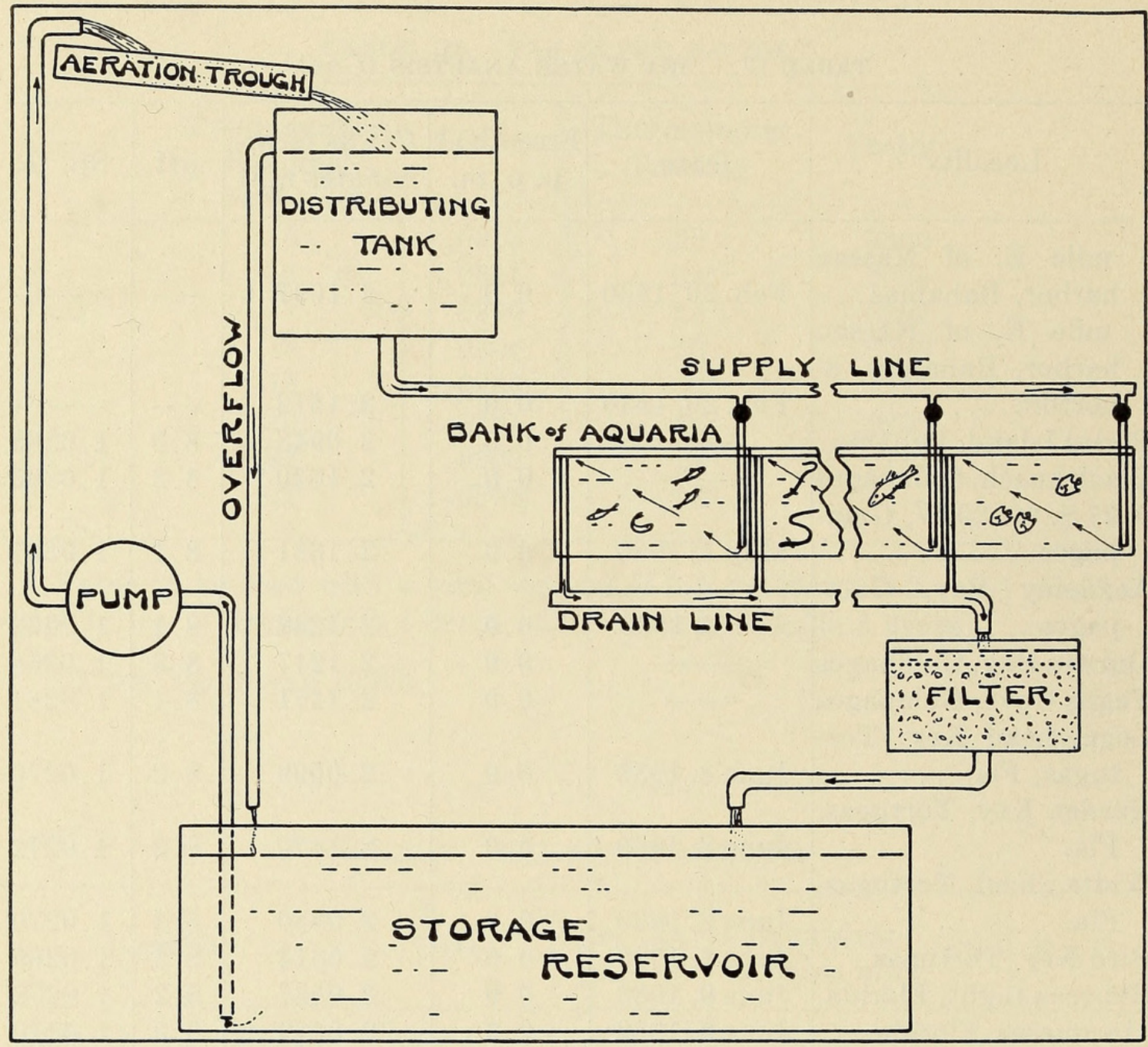

Fig. 332. Diagram of closed salt water system in the New York Aquarium. A heating coil is operated in the "distributing tank" when necessary. The aeration trough as shown is inadequate. 


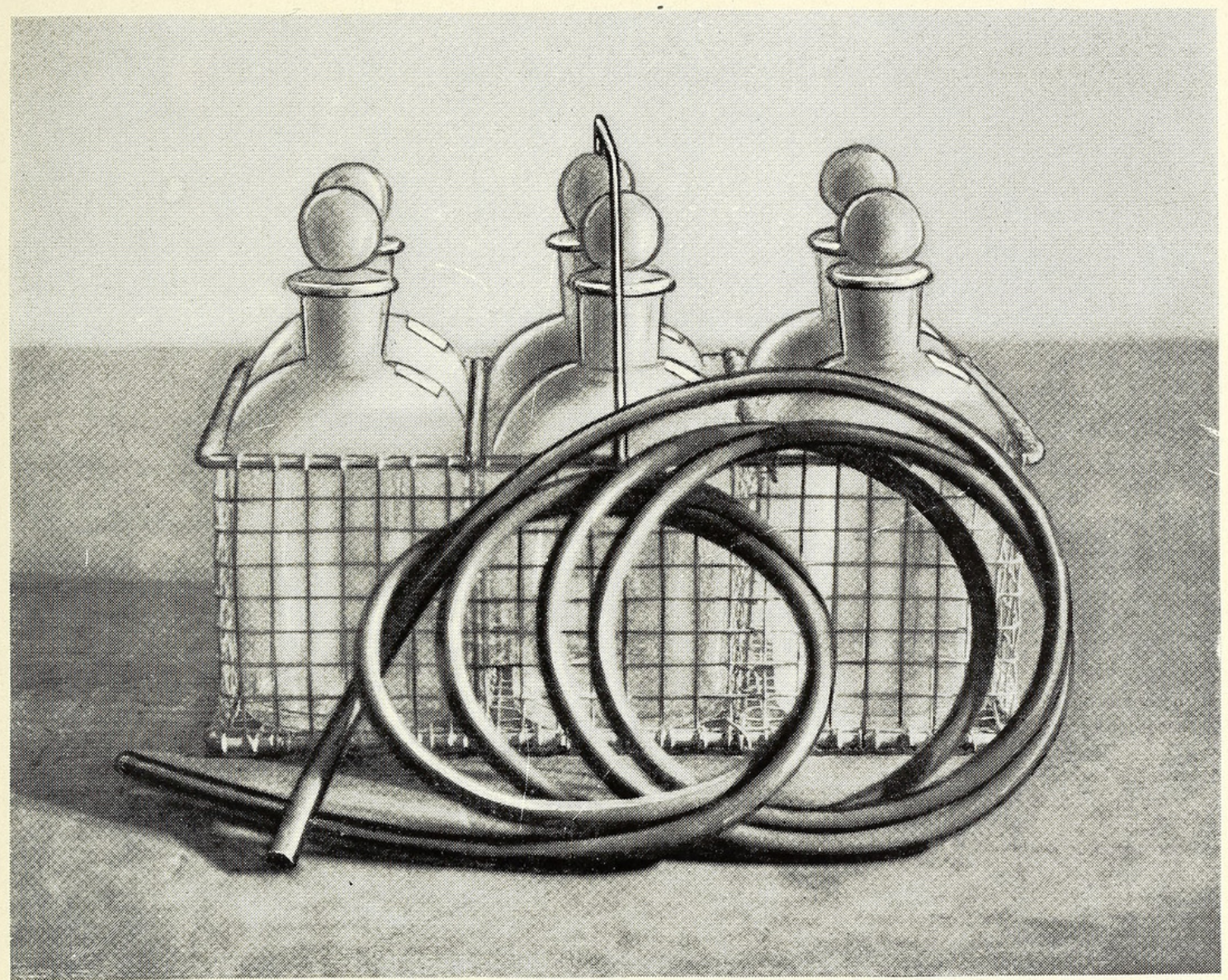

Fig. 333. Equipment used for collecting water samples for analysis. 


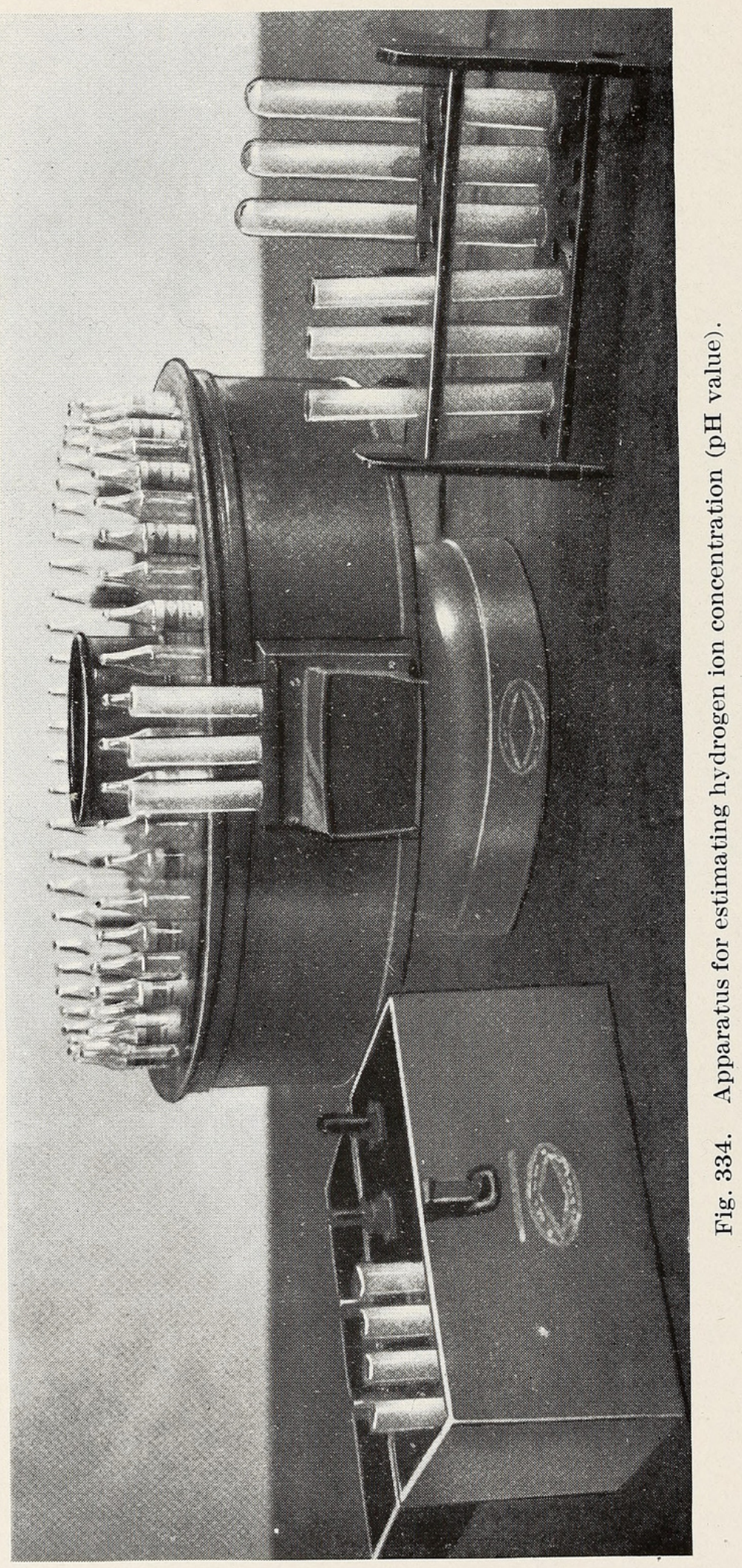




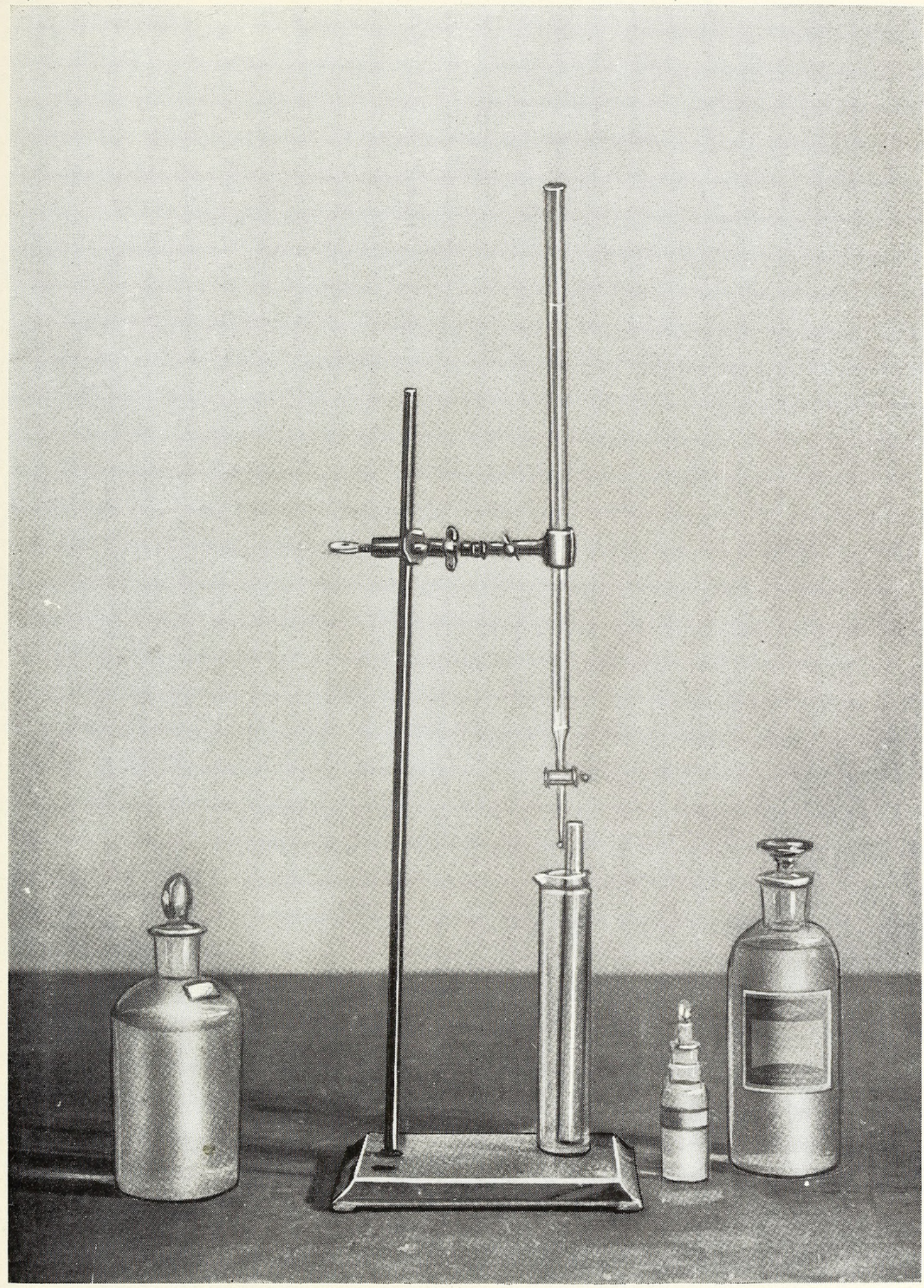

Fig. 335. Titration apparatus for estimating free carbon dioxide. 


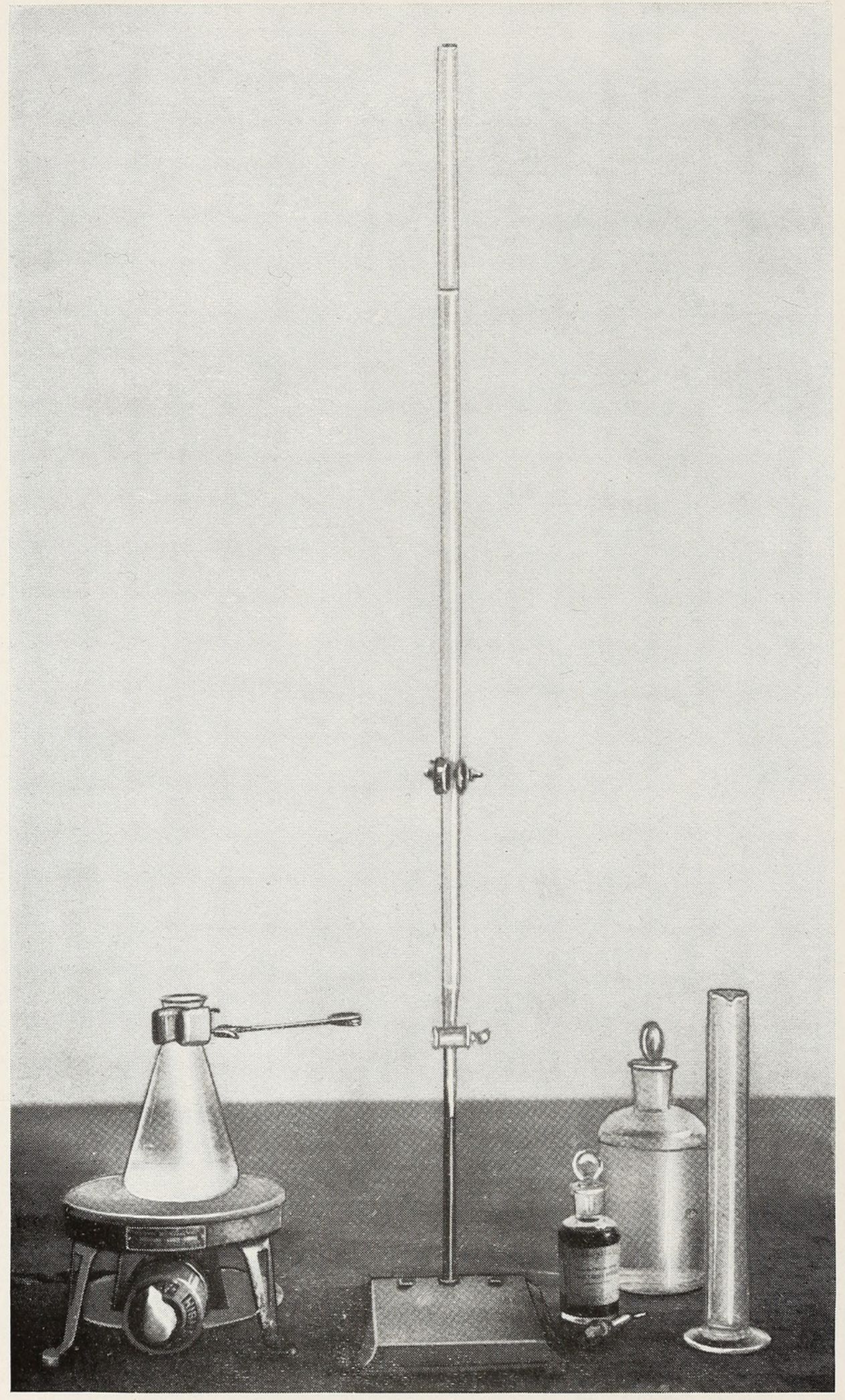

Fig. 336. Titration apparatus for estimating bound carbon dioxide. 


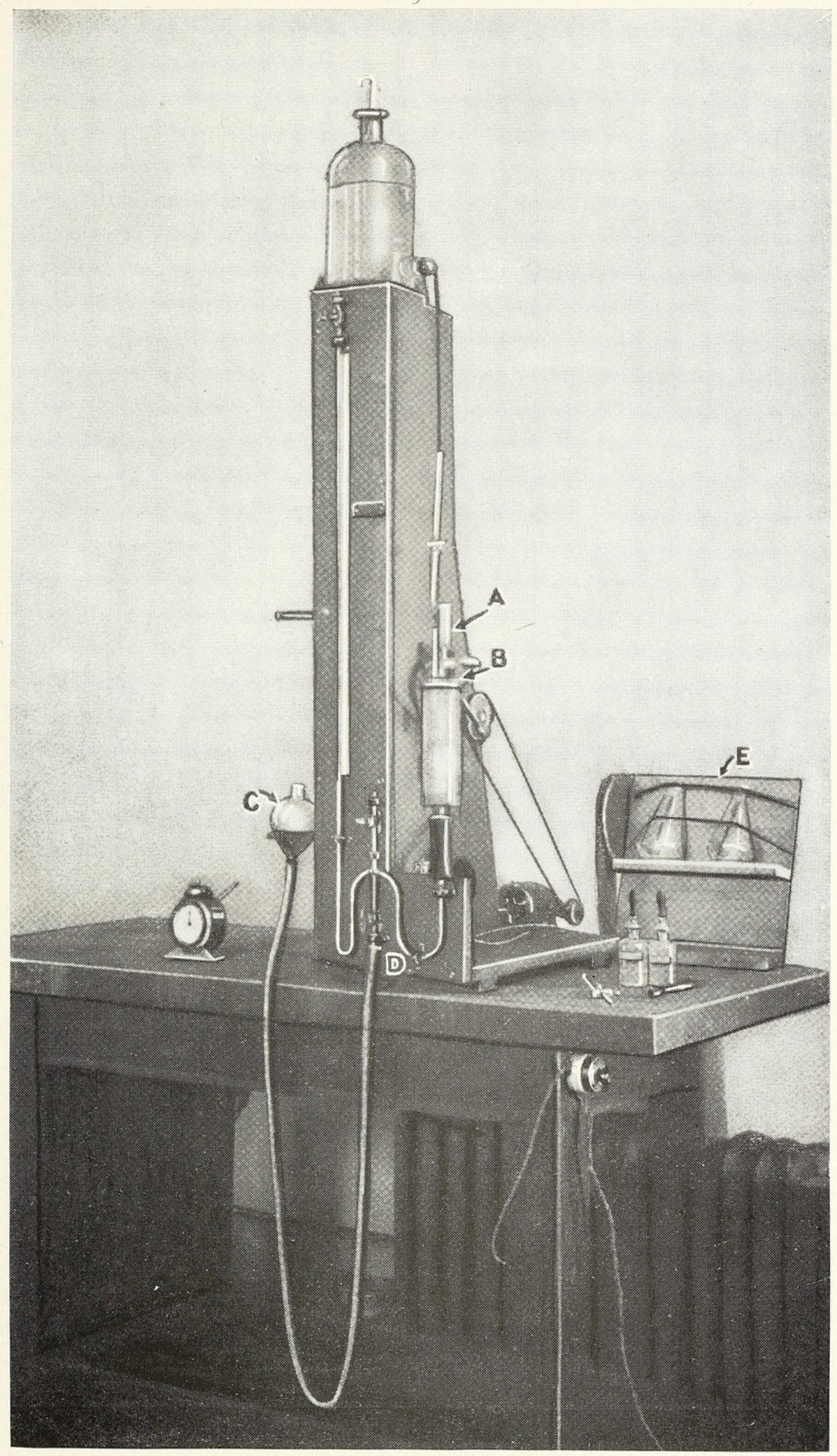

Fig. 337. Van Slyke constant volume manometric apparatus with shaker for liberating free carbon dioxide. A, Graduated cup. B, Two-way cock. C, Mercury Reservoir. D, Stop cock. E, Shaking rack. 


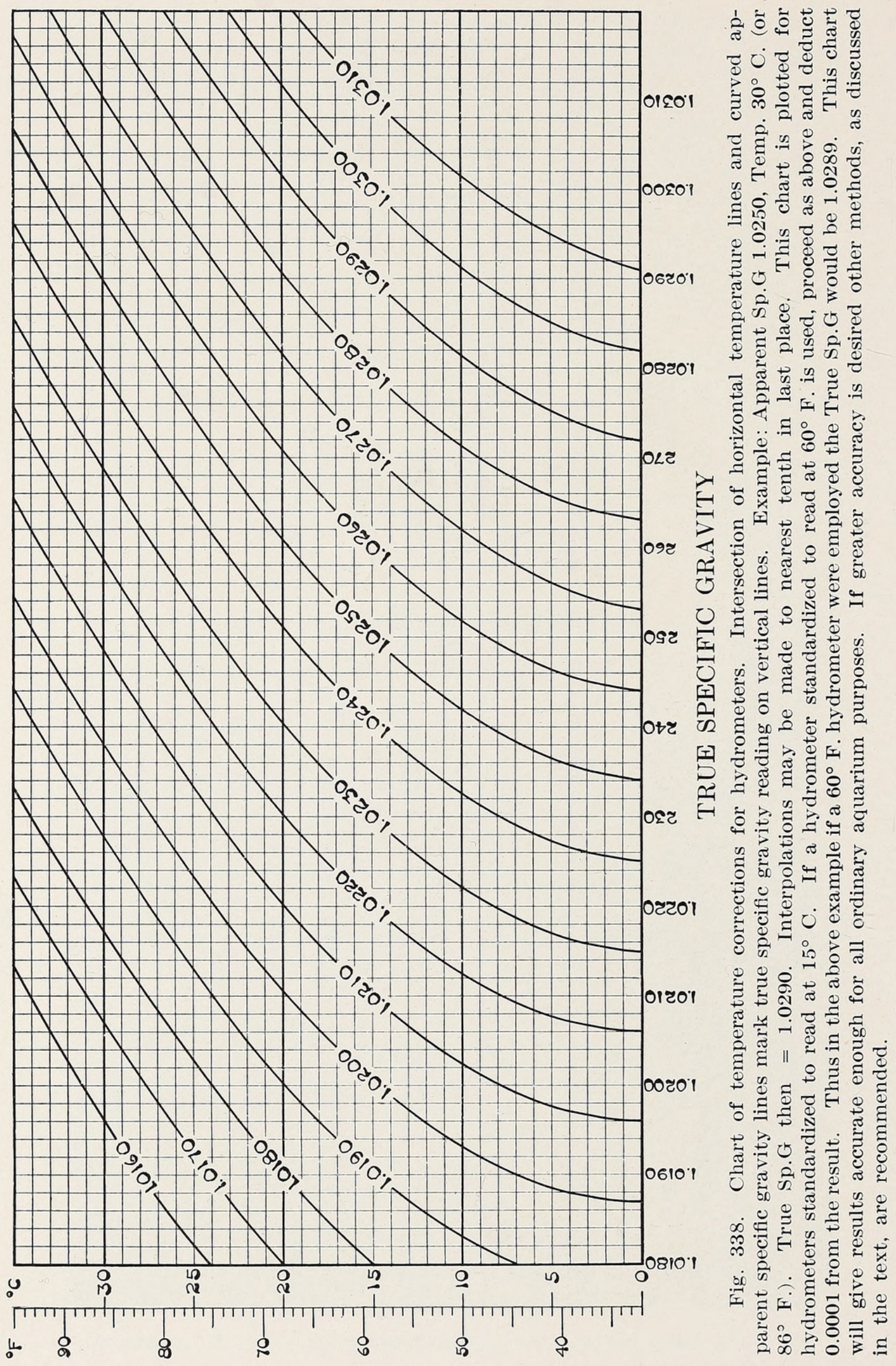




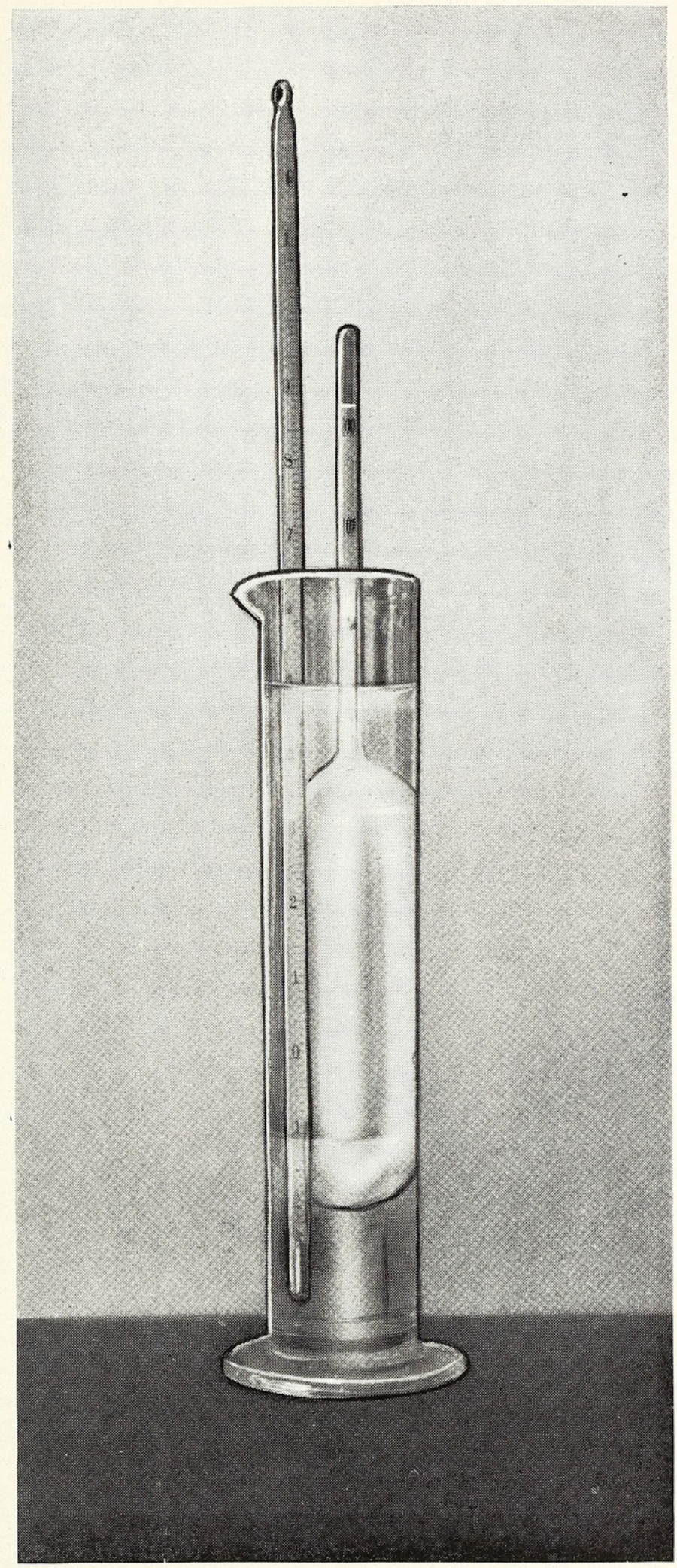

Fig. 339. Hydrometer for determining density of sea water. 


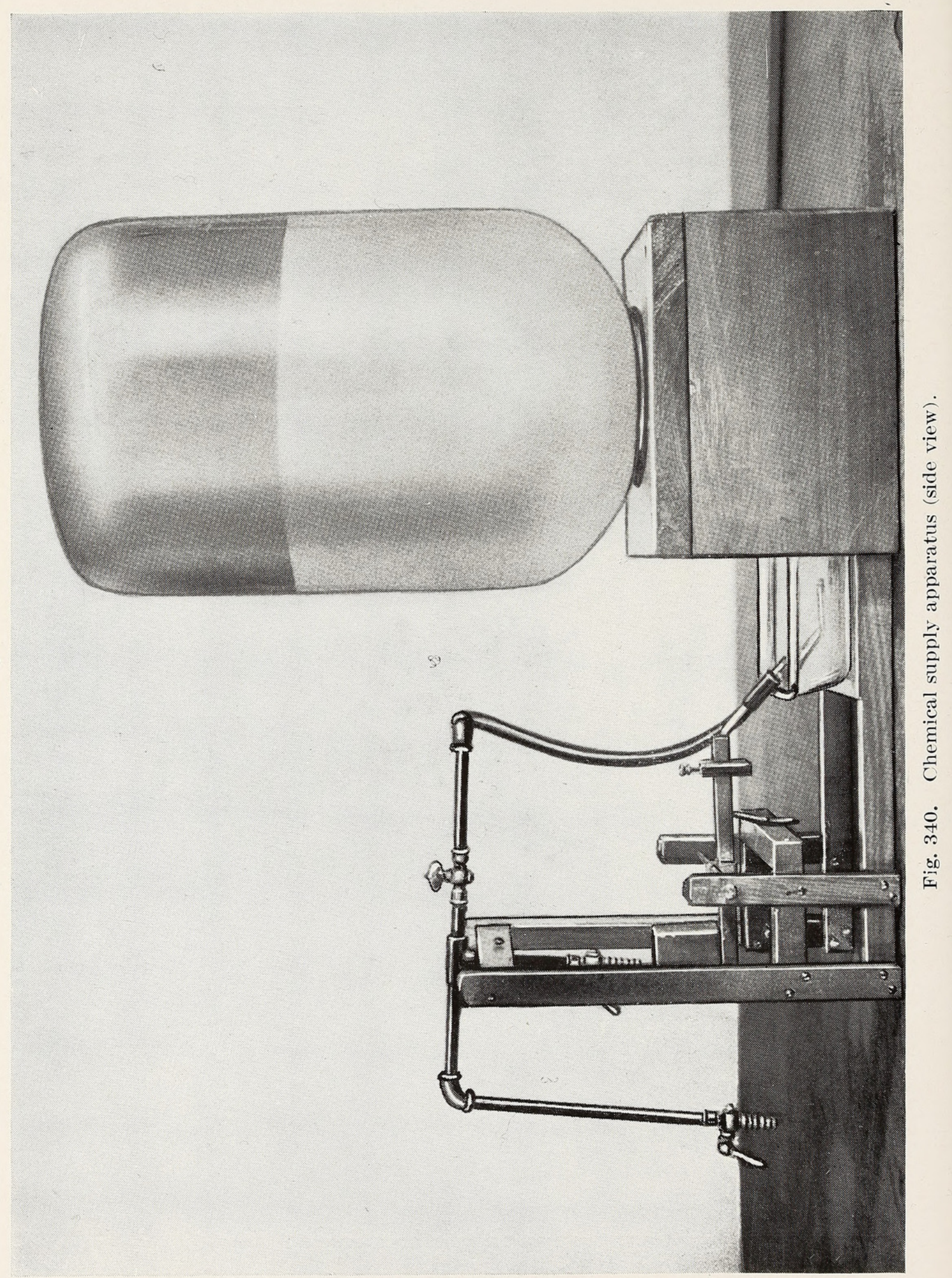




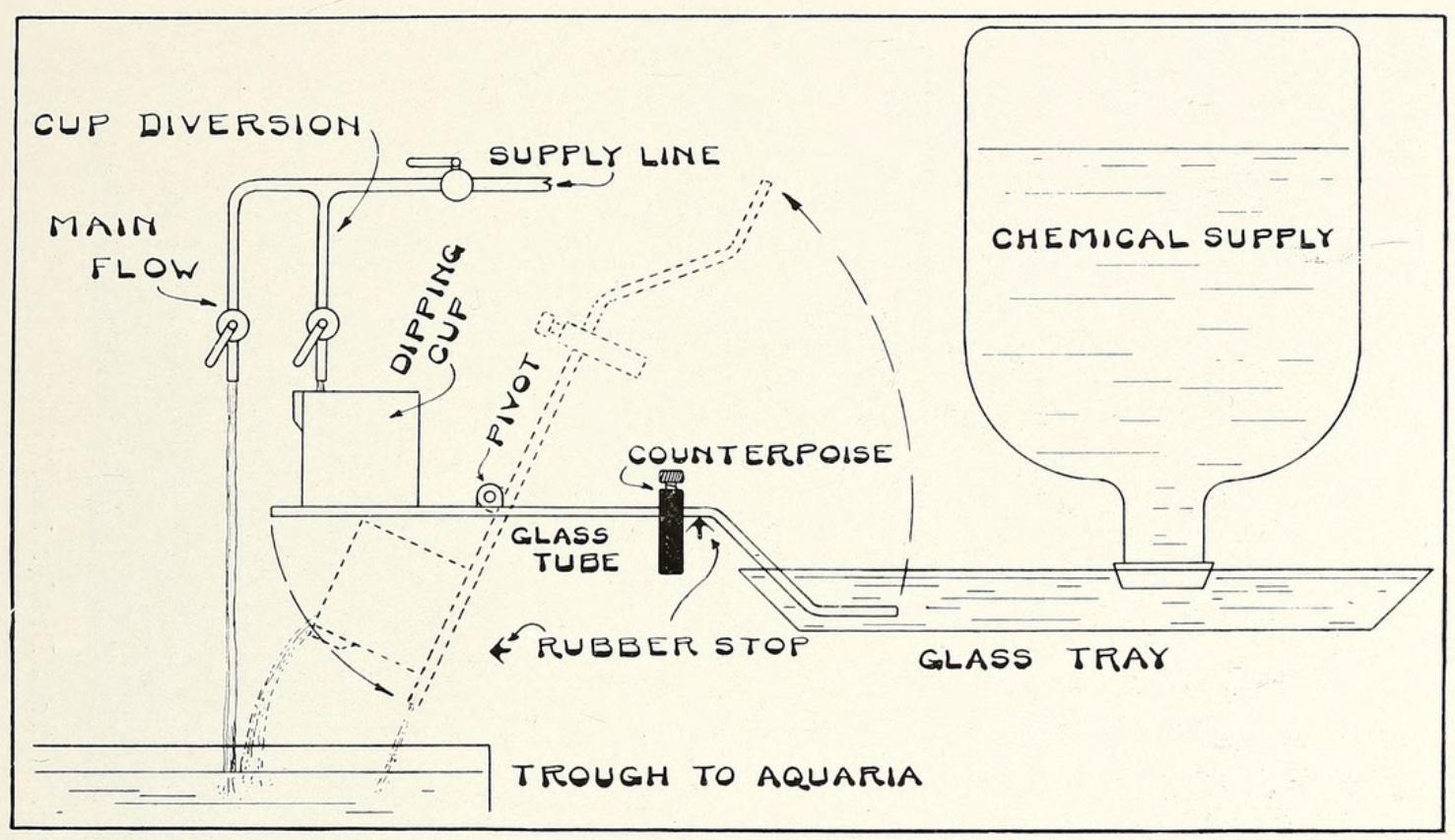

Fig. 341. Diagram of operation of chemical supply apparatus. 


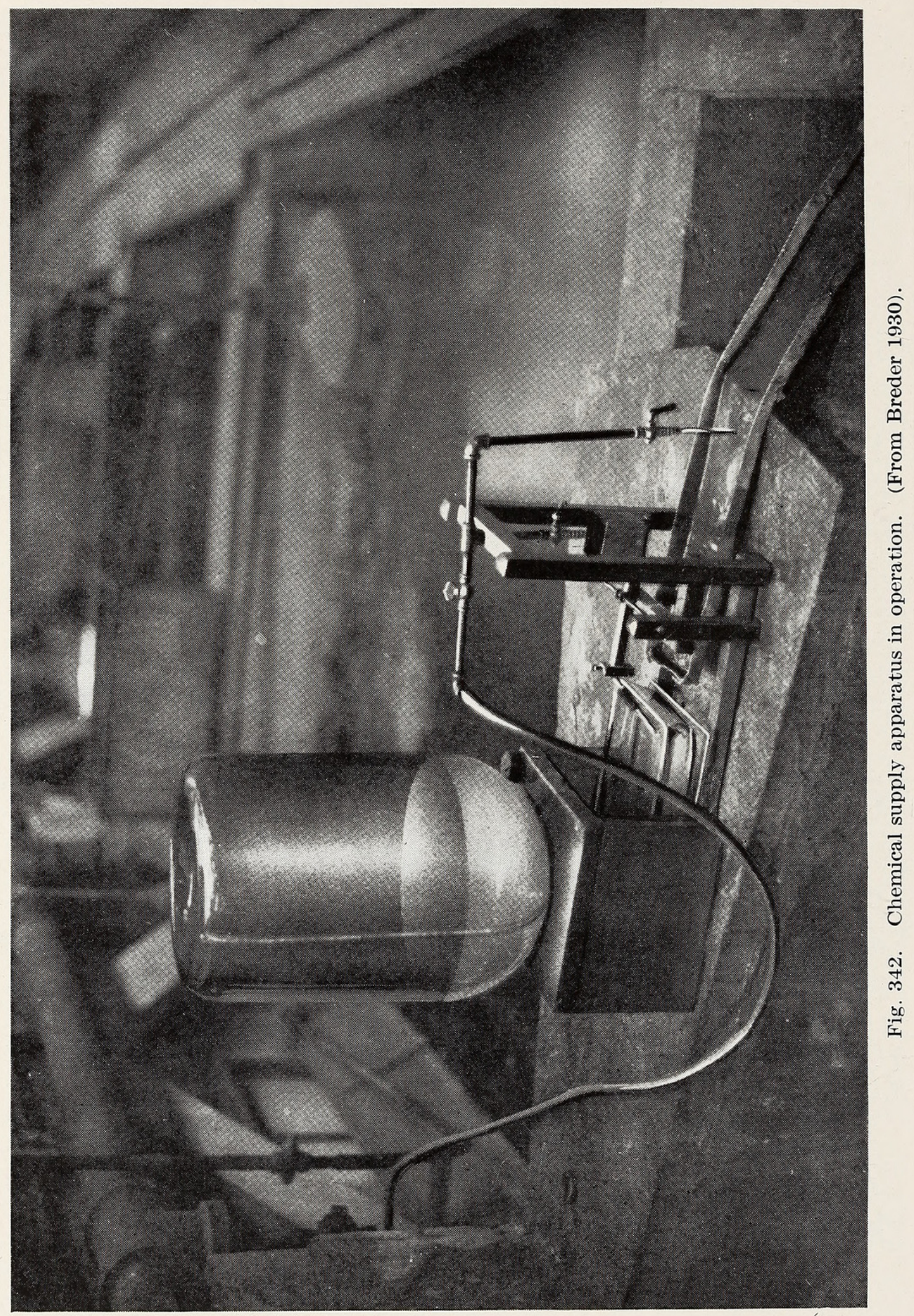




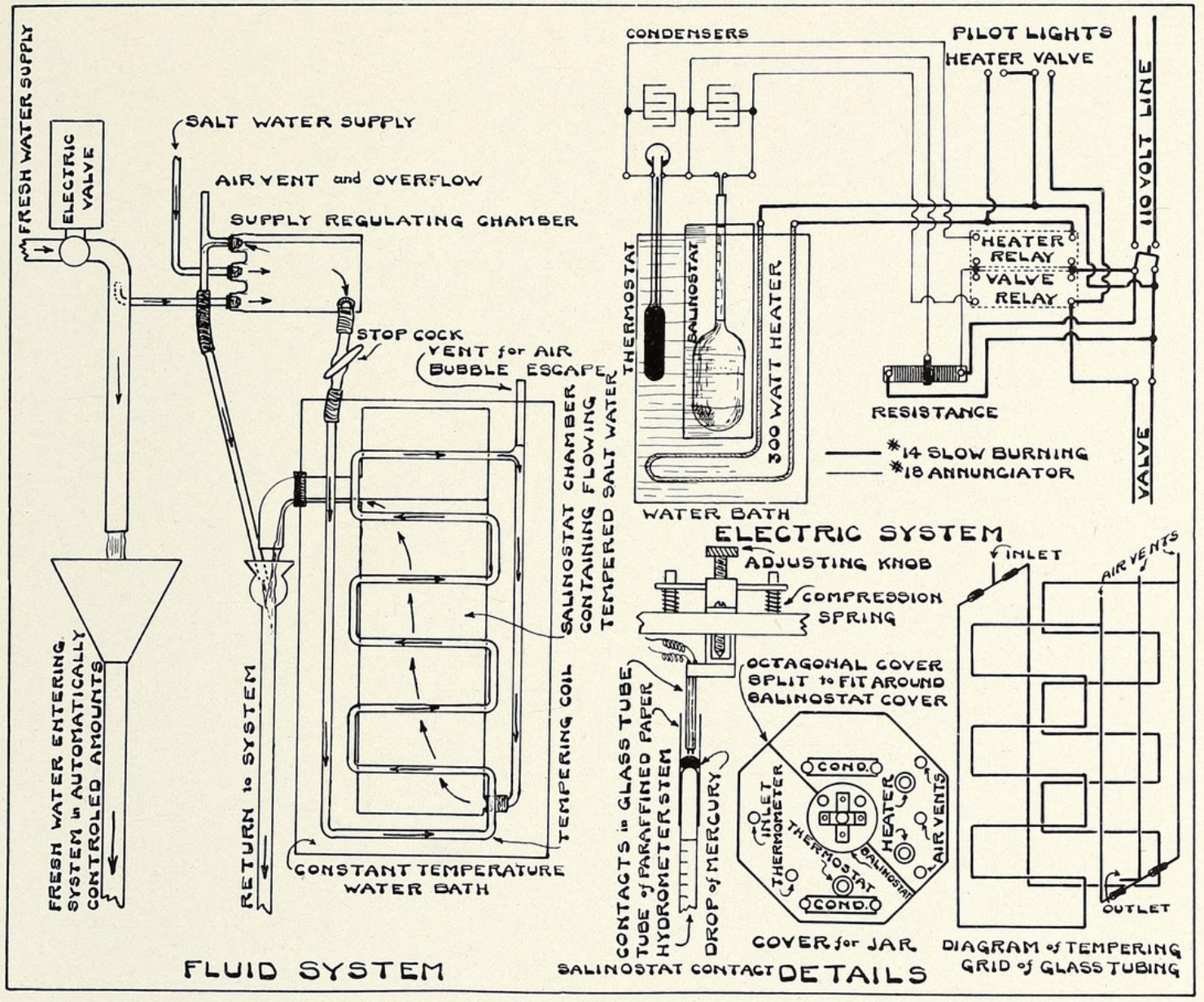

Fig. 343. Diagram and details of salinostat. 


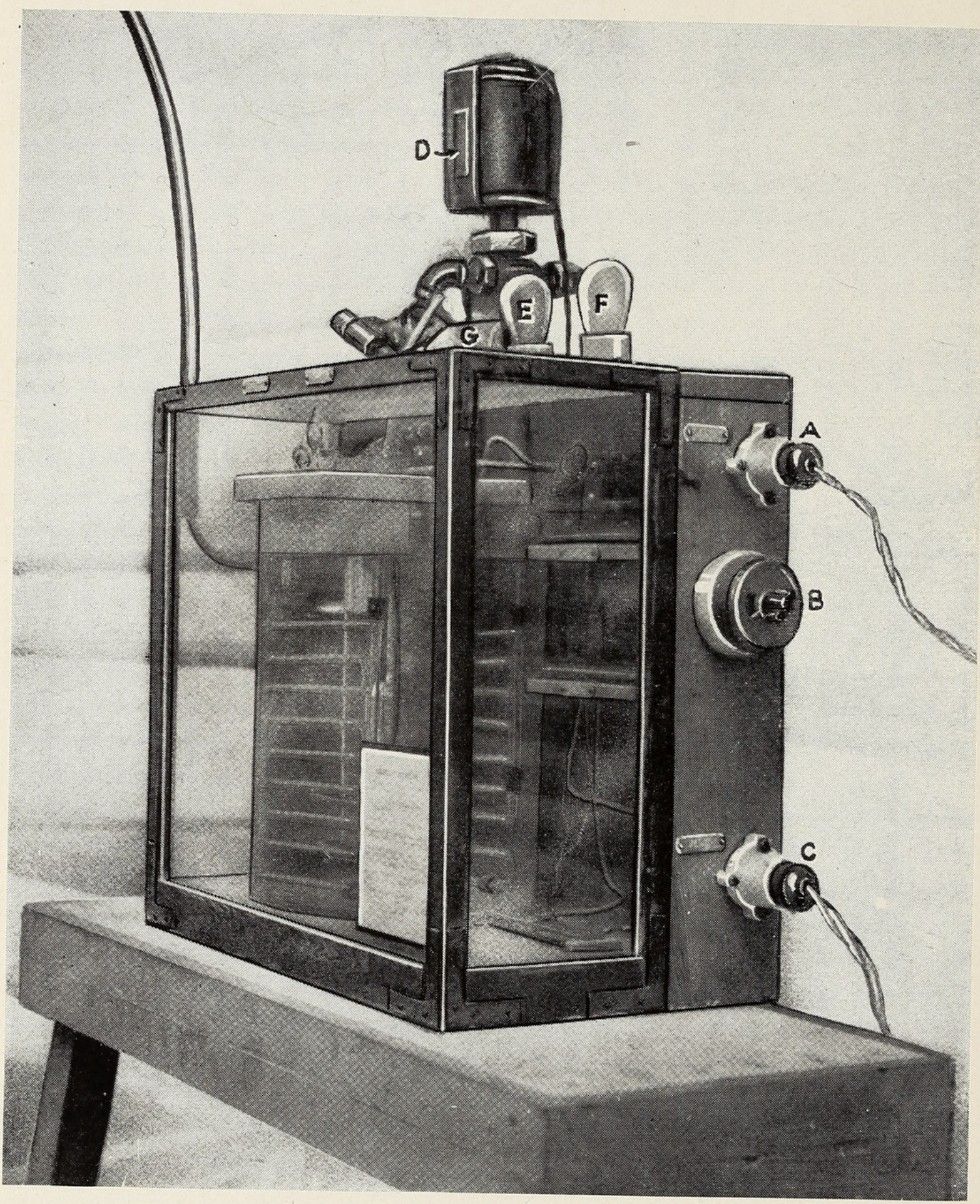

Fig. 344. Salinostat. A-110 volt line; B-Control Switch; C-Solenoid line; DSolenoid valve; E-Heater pilot (yellow); F-Valve pilot (blue); G-Supply regulating chamber. 


\section{$2 \mathrm{BHL}$ Biodiversity Heritage Library}

Breder, Charles M. and Howley, T H . 1931. "The chemical control of closed circulating systems of sea water in aquaria for tropical marine fishes." Zoologica : scientific contributions of the New York Zoological Society 9(11), 403-442. https://doi.org/10.5962/p.203751.

View This Item Online: https://www.biodiversitylibrary.org/item/208079

DOI: https://doi.org/10.5962/p.203751

Permalink: https://www.biodiversitylibrary.org/partpdf/203751

\section{Holding Institution}

Smithsonian Libraries

\section{Sponsored by}

Biodiversity Heritage Library

\section{Copyright \& Reuse}

Copyright Status: In Copyright. Digitized with the permission of the rights holder

Rights Holder: Wildlife Conservation Society

License: http://creativecommons.org/licenses/by-nc/3.0/

Rights: https://www.biodiversitylibrary.org/permissions/

This document was created from content at the Biodiversity Heritage Library, the world's largest open access digital library for biodiversity literature and archives. Visit BHL at https://www.biodiversitylibrary.org. 